\title{
UWZGLĘDNIENIE SKARGI KASACYJNEJ PRZEZ SĄD NAJWYŻSZY JAKO PODSTAWA ŻĄDANIA NAPRAWIENIA SZKODY WYRZĄDZONEJ PRZEZ WYDANIE PRAWOMOCNEGO ORZECZENIA NIEZGODNEGO Z PRAWEM
}

\section{WPROWADZENIE}

Przez pierwszych 12 lat obowiązywania regulacji prawnej umożliwiającej dochodzenie od Skarbu Państwa naprawienia szkody wyrządzonej przez wydanie prawomocnego orzeczenia niezgodnego z prawem (art. $417^{1} \S 2$ k.c.) zapadło jedynie niewiele ponad 50 orzeczeń pozytywnych dla skarżących ${ }^{1}$. Wszystkie te rozstrzygnięcia uczyniłem przedmiotem innej mojej wypowiedzi, wskazując te naruszenia prawa materialnego oraz prawa procesowego, które jak dotąd uzasadniały stwierdzenie, że prawomocne orzeczenie jest niezgodne z prawem w rozumieniu art. $417^{1} \S 2$ k.c. Efektem tych badań jest stwierdzenie, że pierwszoplanową przyczyną uwzględnienia skargi o stwierdzenie niezgodności orzeczenia z prawem sa przedawnienie oraz naruszenie standardów orzekania, pod którym mieści się także wadliwe sporządzenie uzasadnienia orzeczenia (art. $328 \S 2$ k.p.c. w zw. z art. $391 \S 2$ k.p.c.) ${ }^{2}$.

Skarga o stwierdzenie niezgodności orzeczenia $\mathrm{z}$ prawem nie jest jednak jedynym środkiem prawnym umożliwiającym dochodzenie naprawienia szkody, o której mowa w art. $417^{1} \S 2$ k.c. Zatem obowiązku wniesienia tej skargi nie ma w przypadku, gdy skarga o stwierdzenie niezgodności orzeczenia z prawem w ogóle nie przysługuje (art. $424^{\text {1b }}$ k.p.c.). Zakres tej regulacji nie ma jednak dużego znaczenia praktycznego, gdyż zasadniczo skarga o stwierdzenie niezgodności orzeczenia z prawem ma szeroki zakres zastosowania.

Największą szkodę może przy tym wyrządzić stronie orzeczenie kończące postępowanie co do istoty sprawy, a od takich orzeczeń skarga stronie służy (art. $424^{1} \S 1$ i 2 k.p.c., art. $519^{2} \S 1$ i 2 k.p.c.). I właśnie z tego powodu na uwage zasługuje drugi wyjątek od obowiązku wniesienia skargi o stwierdzenie nie-

\footnotetext{
${ }^{1}$ Możliwość taką wprowadzono ustawą z 22 grudnia 2004 r. o zmianie ustawy - Kodeks postępowania cywilnego oraz ustawy - Prawo o ustroju sądów powszechnych, wchodząca w życie 6 lutego 2005 r. (uzasadnienie projektu ustawy zawiera druk nr 2696 Sejmu IV Kadencji z 15 marca 2004 r.).

${ }^{2}$ Lemkowski (2017): 35-39. W 2017 r., który nie był przedmiotem badania w tym opracowaniu, uwzględniono 7 skarg, jest to zatem w dalszym ciagu kilka skarg rocznie.
} 
zgodności orzeczenia z prawem, a mianowicie ten przewidziany w art. $424^{1 \mathrm{a}}$ $\S 2$ k.p.c., w myśl którego orzeczenie Sądu Najwyższego wydane na skutek wniesienia skargi kasacyjnej traktuje się jak orzeczenie wydane w postępowaniu wywołanym wniesieniem skargi.

Zbadania wymagają wobec tego skutki takiego orzeczenia Sądu Najwyższego, w którym rozpoznano skargę kasacyjna w kierunku korzystnym dla skarżącego, a więc które doprowadziło albo do uchylenia zaskarżonego wyroku sądu drugiej instancji (art. $398^{15}$ k.p.c.), albo do jego uchylenia i zmiany (art. $398^{16}$ k.p.c.) ${ }^{3}$.

Zachętą do podjęcia studiów w tym obszarze nie sa przy tym jedynie dane liczbowe, z których wszakże dość jednoznacznie wynika, że jakkolwiek skarg z art. $424^{1}$ i n. k.p.c. uwzględnianych jest rocznie jedynie kilka, to skarg kasacyjnych - już kilkaset ${ }^{4}$. Wobec tego potencjalnie częstszym źródłem odpowiedzialności odszkodowawczej Skarbu Państwa za wydanie orzeczeń niezgodnych z prawem mogą być właśnie orzeczenia Sądu Najwyższego wydane w następstwie rozpoznania skargi kasacyjnej, a nie te rozpoznające skargę o stwierdzenie niezgodności orzeczenia z prawem. Poza tym sprawy kasacyjne to sprawy o dużej wartości przedmiotu sporu, a tym samym ich błędne rozstrzygnięcie może być źródłem poważnej szkody strony. Problematyka ta jest interesująca także z tego względu, że wzajemna relacja art. $424^{1 \mathrm{a}} \mathrm{k}$.p.c. względem art. $398^{15}$ k.p.c. oraz art. $398^{16}$ k.p.c., a przede wszystkim w stosunku do art. 415 zd. 2 k.p.c., do którego wspomniane przepisy odsyłaja, nie jest jasno zakreślona i może budzić poważne wątpliwości.

Dodatkowym bodźcem do podjęcia tych badań jest w końcu to, że pozwolą one po trosze na ocenę tego, w jakiej mierze trafne w świetle rozwiąań proceduralnych było przyjęcie w orzecznictwie Sądu Najwyższego jednolitego poglądu, zgodnie z którym z niezgodnością orzeczenia z prawem mamy do czynienia tylko wtedy, gdy jest ono niewątpliwie sprzeczne z zasadniczymi i niepodlegającymi różnej wykładni przepisami, z ogólnie przyjętymi standardami rozstrzygnięć albo zostało wydane w wyniku szczególnie rażąco błędnej wykładni lub niewłaściwego zastosowania prawa ${ }^{5}$. Można bowiem postawić hipotezę, że ustawodawca nie przewidział przestrzeni proceduralnej dla ustalania, czy ma miejsce kwalifikowane naruszenie prawa w przypadku, gdy drogę do naprawienia szkody wyrządzonej deliktem judykacyjnym ma otwierać uwzględnienie skargi kasacyjnej.

${ }^{3} \mathrm{Z}$ uwagi na ramy opracowania poza jego zakresem pozostawić trzeba natomiast skądinąd bardzo dyskusyjną kwestię, jak ocenić z perspektywy art. $424^{1 a}$ k.p.c. postanowienie Sądu Najwyższego odmawiające przyjęcia do rozpoznania skargi kasacyjnej. Brak bowiem podstaw do uznawania za trafne ugruntowanego w orzecznictwie i piśmiennictwie stanowiska, zgodnie z którym odmowa przyjęcia skargi kasacyjnej do rozpoznania ma być równoznaczna z odmowa przyjęcia do rozpoznania skargi o stwierdzenie niezgodności prawomocnego orzeczenia z prawem (względnie z oddaleniem tej skargi).

${ }_{4}$ Por. np. dane przytaczane przez Zembrzuskiego (2015): 244-245.

5 Tak SN w wyroku z 7 lipca 2006 r., I CNP 33/06, OSNC 2007, nr 2, poz. 35. Ujęcie takie sformułował Gudowski (2006): 10-11. 


\section{REGULACJE PRAWNE}

Dodatkowa trudność w określeniu skutków prawnych orzeczenia uwzględniającego skargę kasacyjną z perspektywy art. $417^{1} \S 2$ k.p.c. wiąże się z tym, że regulacja prawna dotycząca tych zagadnień jest rozproszona. Oprócz wskazanego art. $424^{1 a} \S 2$ k.p.c. dotyczą tego również art. $398^{15} \S 1$ in fine k.c. oraz art. $398^{16}$ zd. 2 k.p.c. Przepisy te odnoszą się do sytuacji, w której Sąd Najwyższy kasatoryjnie albo reformatoryjnie uwzględnia skargę kasacyjna, i w obu przypadkach odsyłają do odpowiedniego zastosowania art. 415 k.p.c. Ten zaś przepis przewiduje, że skarżący może złożyć tzw. wniosek restytucyjny, co jednak nie wyłącza możliwości dochodzenia w osobnym procesie, także od Skarbu Państwa, naprawienia szkody poniesionej wskutek wydania lub wykonania wyroku.

Nie uprzedzając nadmiernie dalszych wniosków, podkreślić trzeba już teraz, że niewątpliwie wolą ustawodawcy było to, aby oba przypadki uwzględnienia skargi kasacyjnej, tj. zarówno wydanie przez Sąd Najwyższy wyroku reformatoryjnego, jak i kasatoryjnego, były traktowane jednolicie, jeśli chodzi o odpowiedzialność odszkodowawczą Skarbu Państwa z tytułu wydania niezgodnego z prawem orzeczenia. Nie wprowadzono bowiem żadnego zróżnicowania owych skutków prawnych w zależności od postaci orzeczenia Sądu Najwyższego: w obu przypadkach należy odpowiednio stosować art. 415 k.p.c., a więc $\mathrm{w}$ każdym $\mathrm{z}$ nich strona ma możliwość dochodzenia $\mathrm{w}$ osobnym procesie, także od Skarbu Państwa, naprawienia szkody poniesionej wskutek wydania bezprawnego orzeczenia.

Na tym tle przyznać trzeba, że rola, jaka ma pełnić norma z art. $424^{1 \mathrm{a}} \S 2$ k.p.c., jest niejasna. Biorąc pod uwagę treść dopiero co przytoczonych art. $398^{15}$ $\S 2$ k.p.c. i art. $398^{16}$ k.p.c. w zw. z art. 415 k.p.c., można przyjąć, że w tym zakresie, tj. co do orzeczeń pozytywnych dla skarżących kasacyjnie, art. $424^{1 \mathrm{a} a} \S 2$ k.p.c. stanowi wręcz superfluum. Wszak to, że strona może żądać naprawienia szkody od Skarbu Państwa, wynika już dostatecznie wyraźnie z art. 415 k.p.c., odpowiednio zastosowanego ${ }^{6}$.

Rola art. $424^{\text {1a }} \S 2$ k.p.c. może wobec tego wyczerpywać się w tym, że na jego podstawie da się jedynie zrekonstruować normę, zgodnie z którą oddalenie skargi kasacyjnej „traktuje się jak” oddalenie skargi o stwierdzenie nie-

${ }^{6}$ Co więcej, w uzasadnieniu ustawy wprowadzającej skargę o stwierdzenie niezgodności orzeczenia z prawem (s. 4) wskazuje się, że możliwość orzeczenia wstrzymania wykonania prawomocnego wyroku na podstawie art. 388 k.p.c. „w poważnym stopniu zmniejszy [...] liczbę przypadków, w których za wyrządzoną szkodę musiałby odpowiadać Skarb Państwa na podstawie projektowanego art. $417^{1}$ k.c.”, co dowodzi, że projektodawca wprost liczył się z tego rodzaju odpowiedzialnością. Inną rzeczą jest to, że art. 388 k.p.c. jest wadliwie skonstruowany, gdyż uniemożliwia wstrzymanie wykonania orzeczenia przed wniesieniem skargi kasacyjnej, czyli w praktyce przez okres kilku miesięcy od chwili jego ogłoszenia, a ponadto brak uzasadnienia tego postanowienia oraz brak możliwości wniesienia zażalenia pozwalają twierdzić, że w obecnym brzmieniu art. 388 k.p.c. narusza gwarantowane konstytucyjnie prawo do sądu oraz zasadę dwuinstancyjności. 
zgodności orzeczenia z prawem ${ }^{7}$. Innymi słowy, oddalenie skargi kasacyjnej oznacza, że orzeczenie było zgodne z prawem. Pogląd ten dominuje w piśmiennictwie, choć można mu zarzucić daleko idące uproszczenie, gdyż Sąd Najwyższy rozpoznaje skargę, a nie sprawę, wobec czego kontroluje orzeczenie jedynie pod kątem uchybień wytkniętych w skardze kasacyjnej, wyjąwszy nieważność postępowania braną pod uwagę z urzędu (art. $398^{13} \S 1$ in fine k.p.c.). Nie można zatem zasadnie twierdzić, że oddalenie skargi kasacyjnej oznacza, że zaskarżony wyrok był prawidłowy pod każdym względem ${ }^{8}$. Niemniej abstrahując od uzasadnienia tego stanowiska, stwierdzić trzeba, że z mocy art. $424^{\text {1a }}$ k.p.c. taki właśnie jest skutek prawny oddalenia skargi kasacyjnej. Strona, której skarga kasacyjna została oddalona, nie może dochodzić naprawienia szkody wyrządzonej wydaniem prawomocnego orzeczenia.

\section{STANOWISKO PIŚMIENNICTWA W PRZEDMIOCIE SKUTKÓW UWZGLĘDNIENIA SKARGI KASACYJNEJ Z PERSPEKTYWY ART. $417^{1} \S 2$ K.C.}

Z kolei uwzględnienie skargi kasacyjnej nie jest w literaturze jednolicie postrzegane w kontekście skutków, jakie tego rodzaju orzeczenie wywołuje, jeśli chodzi o dopuszczalność wystapienia z żądaniem naprawienia szkody przez Skarb Państwa z racji wydania niezgodnego z prawem orzeczenia. Zdecydowanie dominuje pogląd, że uwzględnienie skargi kasacyjnej, niezależnie od tego, czy nastapiło wyrokiem reformatoryjnym czy kasatoryjnym, przesądza o niezgodności orzeczenia z prawem: „uchylenie orzeczenia przez Sąd Najwyższy jest równoznaczne ze stwierdzeniem, że prawomocne orzeczenie sądu II instancji było niezgodne z prawem”; „w razie uwzględnienia skargi kasacyjnej, zarówno przez wydanie orzeczenia kasatoryjnego, jak i reformatoryjnego, orzeczenie to ma charakter prejudykatu w ewentualnym procesie odszkodowawczym” "10; „SN uwzględniając skargę kasacyjną i uchylając zaskarżone orzeczenie, $\mathrm{w}$ istocie rzeczy stwierdza niezgodność z prawem kontrolowanego orzeczenia, tym samym spełniona jest przesłanka dochodzenia roszczeń od-

${ }^{7}$ Pomijam w tym miejscu sygnalizowana już, a dyskusyjną kwestię, jak traktować na tle art. $424^{1 \mathrm{a}} \S 2$ k.p.c. postanowienie o odmowie przyjęcia skargi kasacyjnej do rozpoznania.

${ }^{8} \mathrm{Tu}$ jednak trafnie wskazuje projektodawca (s. 6 uzasadnienia), że skutek taki wywołuje strona sama, rezygnując z wytknięcia w skardze kasacyjnej wszystkich wadliwości zaskarżanego przez nią orzeczenia. Raczej należałoby wobec tego przyjąć, że w takim przypadku ma miejsce nie tyle potwierdzenie zgodności z prawem prawomocnego orzeczenia, co nieskorzystanie przez stronę z przysługujących jej środków prawnych (art. $424^{1} \S 1$ k.p.c.).

${ }^{9}$ Ereciński (2016): 298.

${ }^{10}$ Zembrzuski (2015): 240, 259: „w razie uwzględnienia skargi kasacyjnej orzeczenie Sądu Najwyższego ma jednocześnie charakter prejudykatu w ewentualnym późniejszym procesie odszkodowawczym". 
szkodowawczych wskazana w art. $417^{1} \S 2$ k.c." ${ }^{11}$. Stanowisko takie wyrażaja także inni autorzy ${ }^{12}$.

Coraz częściej w literaturze dostrzegane są przy tym trudności wynikające stąd, że z uwagi na odmienne funkcje pełnione przez oba rodzaje skarg w postępowaniu ze skargi kasacyjnej nie ma w ogóle przestrzeni dla stopniowania obrazy prawa, której miał się dopuścić sąd przy wydawaniu zaskarżonego orzeczenia. Dla uwzględnienia skargi kasacyjnej każdy, nawet najlżejszy stopień naruszenia prawa może już skutkować jej uwzględnieniem. Inaczej jest natomiast jeśli chodzi o skargę o stwierdzenie niezgodności orzeczenia z prawem - w tych przypadkach orzecznictwo konsekwentnie oczekuje, że obraza ta będzie rażąca, oczywista i dostrzegalna prima facie. Formułując krótko po wprowadzeniu do systemu prawa skargi o stwierdzenie niezgodności wyroku z prawem skądinąd słuszną systemowo koncepcję, zgodnie z którą odpowiedzialność za wydanie niezgodnego z prawem orzeczenia musi dać się pogodzić $\mathrm{z}$ istotą władzy sądowniczej, pominięto, jak się wydaje, ten aspekt problemu. Nie odpowiedziano wówczas na pytanie, czy także w przypadku, gdy możliwość żądania naprawienia szkody otwiera się z chwilą uwzględnienia skargi kasacyjnej, należy poszukiwać rażącej obrazy prawa, a w przypadku odpowiedzi twierdzącej - kto (jaki sąd) i w którym postępowaniu miałby to czynić.

Wypowiadający się na ten temat autorzy prezentują wszystkie możliwe stanowiska. Ci, którzy w ogóle nie dostrzegaja problemu, jak należy sądzić, opowiadaja się za koncepcja, zgodnie z którą stopień bezprawności wyroku uchylonego albo także zmienionego przez Sąd Najwyższy jest bez znaczenia, jeśli chodzi o odpowiedzialność z art. $417^{1} \S 2$ k.c. Wypowiedzi te zostały już przytoczone, przy czym niektórzy wprost dostrzegając tę problematykę, konkluduja, że także w tych przypadkach, w których niezgodności z prawem zaskarżonego kasacyjnie orzeczenia nie można uważać za kwalifikowana, nie wpłynie to ujemnie na istnienie odpowiedzialności odszkodowawczej władzy publicznej ${ }^{13}$.

Na drugim biegunie znajduje się z kolei odosobnione stanowisko stwierdzające, że dla przyjęcia odpowiedzialności odszkodowawczej Skarbu Państwa konieczne miałoby być stwierdzenie wprost w uzasadnieniu orzeczenia wydanego przez Sąd Najwyższy, że doszło do naruszenia prawa o charakterze rażącym, kwalifikowanym ${ }^{14}$. Pogląd ten jest słusznie krytykowany przez trafne stwierdzenie, że uzależnianie tej kwestii od treści uzasadnienia orzeczenia wydaje się wątpliwe ${ }^{15}$. Sąd Najwyższy, rozpoznając skargę kasacyjną, w żadnym razie nie ma obowiąku rozprawiania nad tym, w jakim stopniu zaskarżone orzeczenie dopuszcza się obrazy prawa. Skoro obowiązku takiego brak, nie można na tej podstawie twierdzić, że brak stwierdzenia o rażącym, kwalifikowanym naruszeniu prawa przez wydanie orzeczenia miałby wykluczać

${ }^{11}$ Bagińska (2006): 346.

${ }_{12}$ Tak np. Wiśniewski (2013): 262, 363; Skoczylas (2005): 257; Banaszczyk (2015): 267-268, 876; Gęsiak (2007): 93. Mniej jednoznacznie Pietrzkowski (2005): 5-6.

${ }^{13}$ Banaszczyk (2015): 268.

14 Sieńko (2015): 1119.

${ }^{15}$ Zembrzuski (2015): 240. 
zagwarantowane konstytucyjnie prawo strony do dochodzenia naprawienia szkody wyrządzonej przez niezgodne z prawem działanie władzy publicznej (art. 77 ust. 1 Konstytucji RP).

\section{STANOWISKO ORZECZNICTWA}

Uwzględnienie skargi kasacyjnej w świetle art. $424^{1 a} \S 2$ k.p.c. było również trzykrotnie przedmiotem zainteresowania Sądu Najwyższego. Pierwsza wypowiedzią było postanowienie z 26 listopada 2010 r. ${ }^{16}$, które - choć była to jedynie decyzja odmawiajacca przyjęcia skargi kasacyjnej do rozpoznania - stało się następnie podstawą do pojawienia się w orzecznictwie konkurencyjnego dla dominującego $\mathrm{w}$ nauce poglądu zrównującego uwzględnienie skargi kasacyjnej z prejudykatem w rozumieniu art. $417^{1} \S 2$ k.c. Z uwagi na znaczenie tego stanowiska, jako wyrażonego po raz pierwszy, wymaga ono dokładnego przytoczenia: „Skarżący przedstawił tezę, że skoro skarga na niezgodność z prawem prawomocnego orzeczenia nie przysługuje od orzeczeń zaskarżonych skarga kasacyjna, to wydane przez Sąd Najwyższy orzeczenie uwzględniające skargę kasacyjna należy traktować tak samo, jak orzeczenie stwierdzające niezgodność z prawem. Teza ta jednak nie została przekonywająco uzasadniona. Oczywiste jest natomiast, że uchylenie orzeczenia sądu drugiej instancji na skutek uwzględnienia skargi kasacyjnej może nastapić z różnych przyczyn, wśród których może być również oczywista zasadność skargi, wykazującej oczywiste, kwalifikowane naruszenie prawa. W takim tylko wypadku stwierdzenie przez Sąd Najwyższy naruszenia może być ewentualnie traktowane tak samo, jak w przypadku orzeczenia wydanego na podstawie art. $424^{1}$ k.p.c. W innym wypadku tego rodzaju skutek nie powstaje. W uzasadnieniu wniosku o przyjęcie skargi kasacyjnej skarżący nie przedstawił poglądów doktryny bądź judykatury kwestionujących to powszechnie przyjęte stanowisko".

Wyrażone przez Sąd Najwyższy stanowisko w sposób całkowicie nieuzasadniony pomija normę ujęta aktualnie w art. $424^{1 \mathrm{a}} \S 2$ k.p.c., odmienne funkcje pełnione przez oba rodzaje skarg, jak i to, że pogląd zrównujący uwzględnienie skargi kasacyjnej z uwzględnieniem skargi o stwierdzenie niezgodności z prawem, wyjąwszy jeden głos odmienny, w piśmiennictwie zdecydowanie dominuje. Raz jeszcze podkreślić trzeba, że rozpoznając skargę kasacyjną Sąd Najwyższy w żadnym razie nie ma obowiązku badania, czy zachodzi kwalifikowane naruszenie prawa czy nie, a więc jak najbardziej może mieć miejsce sytuacja, w której naruszenie takie zachodzi, ale nie zostało wytknięte w uzasadnieniu i nie można tą drogą ograniczać stronie dochodzenia uprawnień zagwarantowanych jej konstytucyjnie.

Zajęte przez Sąd Najwyższy stanowisko zostało następnie podzielone w wyroku tegoż Sądu z 13 czerwca 2013 r. ${ }^{17}$, przy czym od razu łatwo zauważyć, że

16 IV CSK 383/10, niepubl.

17 V CSK 328/12. 
zostało ono mocno rozbudowane. Przede wszystkim podkreślić trzeba, że oba przywoływane orzeczenia Sądu Najwyższego odnoszą się jedynie do orzeczeń kasatoryjnych, uchylajaccych zaskarżone orzeczenie i przekazujacych sprawę do ponownego rozpoznania, z czego można wnosić, że w przypadku orzeczeń reformatoryjnych uwagi te nie znajdują zastosowania. Zróżnicowanie to jest watpliwe, wziąwszy pod uwagę jednolitą treść art. $398^{15} \S 1$ k.p.c. i art. $398^{16}$ k.p.c. pod kątem odesłania do art. 415 k.p.c. Nie wiadomo bowiem zupełnie, dlaczego w jednym przypadku uwzględnienie skargi kasacyjnej miałoby być traktowane inaczej niż w drugim.

Sąd Najwyższy tym razem dostrzegł, że w piśmiennictwie występują rozbieżne stanowiska w przedmiocie tego, czy także w przypadku uwzględnienia skargi kasacyjnej należy poszukiwać kwalifikowanego naruszenia prawa, pominą jednak, że pogląd zrównujący uwzględnienie skargi z prejudykatem w rozumieniu art. $417^{1} \S 2$ k.c. zdecydowanie przeważa. Trafnie natomiast dostrzegł zróżnicowanie funkcji obu skarg, a więc to, że przyczyną uchylenia orzeczenia sądu drugiej instancji w postępowaniu kasacyjnym wcale nie musi być kwalifikowane naruszenie prawa. Ostatecznie jednak Sąd Najwyższy opowiedział się za poglądem, zgodnie z którym samo uchylenie wyroku sądu drugiej instancji przez Sąd Najwyższy nie jest równoznaczne ze stwierdzeniem, że orzeczenie to jest niezgodne $\mathrm{z}$ prawem w rozumieniu art. $417^{1} \S 2$ k.c., co zostało następnie zaaprobowane przez Jacka Gudowskiego ${ }^{18}$.

Ustalenie, że wyrok kasatoryjny nie jest równoznaczny ze stwierdzeniem niezgodności orzeczenia z prawem, zostało po raz kolejny wyrażone i rozwinięte w wyroku Sądu Najwyższego z 5 listopada 2015 r. ${ }^{19}$ Na podkreślenie zasługuje to, że Sąd Najwyższy zauważył niespójność pomiędzy art. $424^{1 a} \S 2$ k.p.c. oraz przyjętym $\mathrm{w}$ swoim orzecznictwie pojmowaniem pojęcia niezgodności orzeczenia z prawem. Jednakże nie to spostrzeżenie stanowi najważniejsze novum, lecz to, że zdaniem Sądu Najwyższego „w sytuacji określonej w art. $424^{1 a}$ $\S 2$ k.p.c. sąd oceniając przesłanki odpowiedzialności Skarbu Państwa na podstawie art. $417^{1} \S 2$ k.c., dokonuje kwalifikacji uchybień sądu drugiej instancji stwierdzonych przez Sąd Najwyższy w wyroku kasatoryjnym, jeżeli oczywista niezgodność orzeczenia z prawem nie została wyraźnie stwierdzona przez ten Sąd". Wedle tego poglądu, kontroli uchylonego przez Sąd Najwyższy wyroku pod kątem rażącej niezgodności z prawem ma dokonać dopiero sąd okręgowy (art. 17 pkt $4^{4}$ k.p.c.) w sprawie o odszkodowanie.

\section{STANOWISKO WLASNE}

Przedstawiona ewolucja poglądów orzecznictwa Sądu Najwyższego, na tle jak do tej pory stabilnych poglądów piśmiennictwa, skłania do krytycznej refleksji nad aktualnym stanowiskiem judykatury. Stanowisko to wymaga

18 Gudowski (2016): 478-479.

19 V CSK 122/15. 
zmiany, celem przywrócenia należytej rangi zarówno skardze o stwierdzenie niezgodności z prawem, jak i skardze kasacyjnej, a nade wszystko zaprzestania wręcz lekceważącej wykładni niebudzących wątpliwości norm wyrażonych w art. $424^{1 \mathrm{a}} \S 2$ k.p.c. oraz art. $398^{15} \S 1$ k.p.c. i art. $398^{16}$ k.p.c. w zw. z art. 415 zd. 2 k.p.c.

Rozwiąania proceduralne nie przewiduja odrębnego postępowania, w ramach którego miałoby być badane to, czy stopień naruszenia prawa, którego dopuścił się sąd w wyroku uchylonym na skutek uwzględnienia skargi kasacyjnej, jest kwalifikowany, a skoro tak, to oceny takiej się nie dokonuje. Mimo to, znając podejście judykatury do zagadnienia odpowiedzialności Skarbu Państwa za wydanie błędnego orzeczenia, można było się spodziewać wniosku wyrażonego w wyroku Sądu Najwyższego z 5 listopada 2015 r., że oceny pod tym kątem ma jednak dokonywać sąd meriti, rozpoznający sprawę o odszkodowanie $\mathrm{z}$ art. $417^{1} \S 2$ k.c. Jednakże wniosek taki nie ma żadnego oparcia $\mathrm{w}$ przepisach prawa, a do tego przeczy założeniom przyjmowanym na etapie wprowadzania do systemu prawa skargi o stwierdzenie niezgodności orzeczenia $\mathrm{z}$ prawem.

Wolą ustawodawcy było, aby ocena, czy orzeczenie narusza prawo w stopniu uzasadniającym naprawienie szkody przez Skarb Państwa, dokonywana była wyłącznie przez Sąd Najwyższy. Właśnie dlatego powołany został odrębny instrument prawny - skarga o stwierdzenie niezgodności orzeczenia z prawem, poddany kognicji Sądu Najwyższego i mający charakter prejudycjalny, który to środek wespół ze skargą kasacyjną miał prowadzić do eliminowania orzeczeń niezgodnych z prawem. Nie można przy tym pomijać, że to właśnie orzeczenia kończące postępowanie w sprawie mają największy negatywny potencjał, jeśli chodzi o możliwość wyrządzenia stronie szkody. Skoro wobec tego z woli ustawodawcy to Sąowi Najwyższemu powierzono orzekanie w tych sprawach, wykładnia prawa nie powinna zmierzać do delegowania tej kompetencji do sądów powszechnych, nawet jeśli okazuje się, że rozpoznając skargę kasacyjna, Sąd Najwyższy nie ma obowiązku badania, w jakim stopniu uchylane orzeczenie narusza prawo. Powinno pozostawać bezsporne, że sądy powszechne mogą dokonywać takiej oceny jedynie w zakresie, o jakim mowa $\mathrm{w}$ art. $424^{1 \mathrm{~b}}$ k.p.c., czyli mimo wszystko w sprawach mniejszej wagi, o mniejszym znaczeniu. Sprawy, o których mowa w art. $424^{1 \text { a }} \S 2$ k.p.c., pod katem bezprawności judykacyjnej badane są wyłącznie przez Sąd Najwyższy.

Wprawdzie w piśmiennictwie postuluje się niekiedy nawet rezygnację ze skargi o stwierdzenie niezgodności orzeczenia z prawem na rzecz powierzenia tych zadań w pełni sądom powszechnym, jedynie pod kontrolą judykacyjna Sądu Najwyższego, ale sa to jedynie postulaty de lege ferenda ${ }^{20}$. Zważywszy na to, że skarga kasacyjna przysługuje w sprawach o dużej wartości przedmiotu sporu, jak również uwzględniając proporcje uwzględnianych rocznie skarg kasacyjnych (nawet kilkaset) do skargi o stwierdzenie niezgodności orzeczenia z prawem (kilka), łatwo zauważyć, że jeśli pogląd o badaniu orzeczenia pod kątem istnienia kwalifikowanego naruszenia prawa przez sąd powszechny

${ }^{20}$ Zembrzuski (2015): 254-255. 
dopiero w sprawie o naprawienie szkody miałby być trafny, oznaczałoby to nieuprawnione przesunięcie kompetencji w dół, z Sądu Najwyższego do sądów powszechnych. Dodatkowo zignorowany zostałby postulat wyrażany w literaturze, stanowczo sprzeciwiający się stanowisku, aby sąd cywilny rozpoznający roszczenie odszkodowawcze skierowane przeciwko Skarbowi Państwa mógł samodzielnie badać, ustalać i oceniać, czy prawomocne orzeczenie sądowe jest niezgodne z prawem ${ }^{21}$. Doszłoby przy tym do marginalizacji Sądu Najwyższego, ewidentnie wbrew woli ustawodawcy, który kontrolę nad badaniem tego, czy orzeczenie jest niezgodne z prawem czy nie, powierzył w obszarze spraw kasacyjnych właśnie temu sądowi. Wreszcie, przy takim ujęciu strona zostaje zmuszona do tego, aby od razu udowadniać istnienie szkody i jej wysokości, z czego jest zwolniona w przypadku konieczności uzyskania prejudykatu, co powoduje, że jej sytuacja procesowa w gruncie rzeczy jest trudniejsza, bardziej złożona.

Należy wobec tego stanowczo opowiedzieć się za dominującym w piśmiennictwie stanowiskiem, zgodnie z którym uwzględnienie skargi kasacyjnej traktuje się jak uwzględnienie skargi o stwierdzenie niezgodności prawomocnego orzeczenia z prawem (art. $424^{1 \mathrm{a}} \S 2$ k.p.c.). Podstawą żądania naprawienia szkody w takim przypadku jest też art. 415 zd. 2 k.p.c., stosowany odpowiednio przez odesłanie z art. $398^{15} \S 1$ k.p.c. czy z art. $398^{16}$ k.p.c.

Strona, która na swój koszt opracowała, wniosła i popierała skargę kasacyjna, może przyczynić się do rozwoju prawa - wszak skarga kasacyjna pełni również funkcję publicznoprawną. Skoro rozwój prawa dokonuje się w istotnej części na koszt i wysiłkiem strony, zasługuje ona na to, aby wyrok, który wyrządził jej szkodę, a został uchylony albo uchylony i zmieniony, przesądzał o potrzebie jej naprawienia bez jakichkolwiek dalszych ustaleń, wyjąwszy sam rozmiar szkody ${ }^{22}$. Rozwój prawa w postaci wyjaśnienia zagadnienia prawnego czy też usunięcia rozbieżności w orzecznictwie następuje niezależnie od tego, z jak poważnym naruszeniem w zaskarżonym wyroku mieliśmy do czynienia. Tym samym również prawo do odszkodowania od Skarbu Państwa nie powinno zależeć od stopniowania owego uchybienia. Cytowane regulacje prawne sa samowystarczalne dla dochodzenia naprawienia szkody także od Skarbu Państwa. Uwypuklenie, że szkodę ma naprawić także Skarb Państwa, zwraca jednak uwagę na dalsze istotne kwestie.

\section{STOSOWANIE PRZEPISÓW PRAWA MATERIALNEGO}

Odpowiedzialność Skarbu Państwa może mieć w niektórych przypadkach charakter odpowiedzialności in solidum ze stroną postępowania. Jeśli wyrok, który wyrządził szkodę, został następnie uchylony, strona ma oczy-

21 Bieniek (2000): 15; Pietrzkowski (2005): 7.

22 Która to szkoda przecież nie zawsze wystapi, nawet jeśli na etapie postępowania kasacyjnego jej istnienie wydawało się prawdopodobne. 
wiście prawo dochodzić naprawienia szkody z tytułu jego wydania (a także wykonania - art. 415 k.p.c.) od samej strony i często tak właśnie czyni. Niemniej odpowiedzialność Skarbu Państwa w tym zakresie nie ma charakteru odpowiedzialności subsydiarnej, a więc aktualizującej się dopiero z chwila, gdy strona szkody nie naprawi. Jeśli jednak do jej naprawienia przez stronę dojdzie, wówczas oczywiście odpadnie podstawa do dochodzenia naprawienia tej samej szkody po raz drugi przez Skarb Państwa.

Przesunięcie punktu ciężkości w stronę prawa materialnego pozwala także na rozwiązanie problemów dostrzeganych w orzecznictwie, a występujących na przykład wówczas, gdy pierwszy wyrok zostaje uchylony w wyniku skargi kasacyjnej jedynie z przyczyn proceduralnych ${ }^{23}$, a następnie zapada kolejny identyczny co do kierunku, jednakże już bez uchybień procesowych. Czy w takim przypadku strona również ma prawo do domagania się naprawienia szkody przez Skarb Państwa? Odpowiedź brzmi: tak, z tym że w ramach naprawienia szkody strona taka będzie mogła domagać się wynagrodzenia szkody wynikłej co najwyżej z tego, że od razu nie zapadł wyrok prawidłowy, wolny od uchybień.

Do wniosku takiego prowadzi w prosty sposób zastosowanie ogólnych reguł odpowiedzialności odszkodowawczej: należy postawić pytanie, jak przedstawiałby się stan majątkowy danej strony, gdyby od początku zapadł wyrok prawidłowy, i porównać go ze stanem obecnym (tzw. metoda dyferencyjna). Nierzadko w takim przypadku w ogóle żadna szkoda nie wystapi, jeśli ostatecznie wyrok jest dobry. Z konstrukcji skargi kasacyjnej i wydawanych w jej następstwie rozstrzygnięć wynika, że w większości przypadków błąd popełniony przez sąd powszechny zostaje naprawiony przez wydanie orzeczenia prawidłowego, a temu właśnie celowi skarga kasacyjna również służy: nie prowadzi jedynie do rozwoju prawa, ale w jej wyniku rozstrzygana jest konkretna sprawa. Powstała w takim przypadku sytuacja przypomina naprawienie szkody w naturze (restitutio ad integrum) i choć nie jest to w pełni przywrócenie stanu poprzedniego ${ }^{24}$ czy zgodnego z prawem, to jednak oznacza samoistne wyeliminowanie przez wymiar sprawiedliwości wcześniej popełnionego błędu.

Niemniej i w takim przypadku naprawieniu może podlegać szkoda wynikła stąd, że prawidłowy prawomocny wyrok zapadł zbyt późno, dopiero w wyniku skargi kasacyjnej. A w okresie pomiędzy wydaniem wyroku wadliwego i pra-

${ }^{23}$ Nie można przy tym marginalizować takiego przypadku, gdyż dla strony często samo uchylenie wyroku, bez względu na przyczynę tego uchylenia, ma negatywne konsekwencje, choćby w zakresie kosztów czy przedłużania się postępowania. Sąd ma obowiązek znać i prawidłowo stosować nie tylko prawo materialne, ale również prawo procesowe i jego naruszenie w takim samym stopniu co naruszenie prawa materialnego powinno skutkować odpowiedzialnością odszkodowawczą Skarbu Państwa. Służebna rola prawa procesowego nie oznacza, że w świetle art. $417^{1}$ $\S 2$ k.p.c. naruszenie tego prawa winno być inaczej (w domyśle: lżej) traktowane. Zresztą art. $424^{4}$ k.p.c. wprost przewiduje, że skargę o stwierdzenie niezgodności można oprzeć tylko na naruszeniu przepisów postępowania.

${ }^{24}$ Dopiero na skutek wydania prawidłowego wyroku następuje stan zgodny z prawem, więc trudno upatrywać tutaj w ścisłym sensie przywracania jakiegoś wcześniej istniejącego stanu, który miałby odpowiadać prawu. 
widłowego mogą nastapić okoliczności ją wyrządzające (np. niewypłacalność pozwanego). Niekiedy też sam fakt utrzymywania się w posiadaniu określonej rzeczy na skutek błędnego wyroku sam w sobie wyrządza szkodę (np. wtedy, gdy z posiadaniem rzeczy wiąże się możliwość pobierania pożytków. Stan bezprawności wyrządzonej prawomocnym orzeczeniem sądu w takim przypadku w przeszłości trwał, a więc jeśli w wyniku istnienia tego stanu powstała szkoda, podlega naprawieniu, i to nie na podstawie przepisów regulujacych tzw. skargę na przewlekłość postępowania (gdyż przewlekłość może w ogóle nie zachodzić w takim przypadku), ale na podstawie art. $398^{15} \S 2$ k.p.c. i art. $398^{16}$ k.p.c. w zw. z art. 415 zd. 2 k.p.c.

Podkreślić trzeba, że patrząc z perspektywy konstrukcji systemu prawnego, zupełnie czymś innym od uchylenia wyroku nieprawomocnego przez sąd drugiej instancji jest uchylenie prawomocnego wyroku przez Sąd Najwyższy. Błędy sądu pierwszej instancji są w pewnym sensie z założenia dopuszczalne i wpisane w naturę wymiaru sprawiedliwości: po to ustawodawca konstytucyjny zapewnia stronom dwuinstancyjność postępowania, aby te błędy wyeliminować. Nie bez racji rozwój zawodowy sędziów przebiega w ten sposób, że na początku pracy - kiedy z natury rzeczy sędziowie są stosunkowo młodymi osobami o mimo wszystko skromnym doświadczeniu zawodowym i życiowym - orzekają w pierwszej instancji. Orzeczenia sądów drugiej instancji sa natomiast zasadniczo inne: są prawomocne, podlegają wykonaniu, w sposób niepodważalny od chwili ogłoszenia kształtują sytuację prawną stron. Wydaja te orzeczenia sędziowie bardziej doświadczeni, zwykle w składzie trzy-, a nie jednoosobowym, co również uprawnia do tego, aby więcej oczekiwać od jakości wydawanego przez takie gremium orzeczenia. Istnieją zatem podstawy do tego, aby odpowiedzialność Skarbu Państwa za wydawane przez sądy odwoławcze wyroki zachodziła nie tylko wtedy, gdy popełnią one oczywisty, rażący i dostrzegalny prima facie błąd judykacyjny ${ }^{25}$. Z cała pewnością przyczyniłoby się to do lepszej jakości orzekania.

Jakkolwiek będzie to powtórzenie, należy po raz kolejny zaznaczyć, że nie ma żadnych podstaw do różnicowania pod kątem możliwości wystapienia z powództwem o odszkodowanie wyroków kasatoryjnych i reformatoryjnych wydawanych przez Sąd Najwyższy w wyniku rozpoznania skargi kasacyjnej.

25 Skądinąd trudno zgodzić się ze stanowiskiem, że w tak ważnej społecznie działalności, jaka jest wymierzanie sprawiedliwości, odpowiedzialność odszkodowawcza ma być ponoszona tylko za rażące błędy, podczas gdy w każdej innej (także związanej ze stosowaniem prawa) błąd nawet najlżejszy skutkuje często bardzo poważną odpowiedzialnościa, nie tylko cywilną. Wydaje się, że powinno być raczej odwrotnie: im bardziej doniosłe społecznie jest działanie danego podmiotu, tym wyższy próg staranności powinno się mu wyznaczać, a więc odpowiedzialność za sprawowanie władzy publicznej nie powinna być ograniczana jedynie do kardynalnych błędów. Należałoby wobec tego tak ukształtować zasadę odpowiedzialności Skarbu Państwa za wydanie niezgodnego z prawem orzeczenia, aby sąd mógł się z niej uwolnić, o ile wykaże, że przyjęty przez niego sposób zastosowania prawa dawał się usprawiedliwić w świetle przepisów prawa, orzecznictwa i literatury, a więc przy zastosowaniu konstrukcji domniemania bezprawności wyroku uchylonego albo uchylonego i zmienionego przez Sąd Najwyższy. Ukształtowanie takich zasad powinno jednak nastapić w ustawie, a nie jedynie w procesie wykładni prawa, oraz należałoby je poprzedzić szeroka debatą publiczną i naukowa. 
Lege non distinguente skutki te muszą być jednolite. Późniejsze uchylenie orzeczenia nie usuwa jego bezprawności ex tunc, a jedynie ex nunc, wobec czego jeśli szkoda zdążyła już powstać, wymaga naprawienia. Natomiast fakt, że ostatecznie zapada orzeczenie prawidłowe, może zneutralizować wystapienie szkody albo zmniejszyć jej rozmiar, natomiast nie uchyla to prostego i niepodważalnego wniosku, że poprzedni prawomocny wyrok istniał, był w pewnym okresie bezprawny i dlatego za ten czas uruchomiona została odpowiedzialność Skarbu Państwa z mocy art. $417^{1} \S 2$ k.c.

Jakkolwiek w orzecznictwie nie analizowano jak dotąd na tle art. $424^{\text {la }} \S 2$ k.p.c. wydania przez Sąd Najwyższy wyroku reformatoryjnego, to łatwo przewidzieć, że kolejnym krokiem w tej dyskusji może być stwierdzenie, że także w takim przypadku sąd powszechny ma badać, czy pogwałcenie prawa (popełnione często przez sąd hierarchicznie wyższy niż sąd rozpoznający sprawę o naprawienie szkody) miało charakter rażący. Przecież także wyrok reformatoryjny wydany przez Sąd Najwyższy nie przesądza, czy naruszenie prawa miało charakter kwalifikowany czy nie. Jeśli dopuścić tego rodzaju argumentację, wówczas doszłoby do niezwykle poważnego zmarginalizowania instytucji skargi o stwierdzenie niezgodności orzeczenia z prawem. Dodatkowo art. $417^{1} \S 2$ k.c. w znakomitej większości spraw zawierałby puste odesłanie, gdyż nie byłoby potrzeby stwierdzania we właściwym postępowaniu, że orzeczenie jest niezgodne z prawem, skoro można od razu wystapić z powództwem o naprawienie szkody przeciwko Skarbowi Państwa i wówczas sąd okręgowy miałby badać i oceniać stopień bezprawności wyroku. Z całą pewnością rozwiązania takiego nie można zaaprobować, gdyż przeczy ono wyraźnej woli ustawodawcy, który ocenę tego rodzaju pozostawił w odniesieniu do wszystkich orzeczeń kończących postępowanie w sprawie w rękach Sądu Najwyższego. Nic jednocześnie nie wskazuje na to, aby art. $424^{1 \mathrm{a}} \S 2$ k.p.c. miał mieć działanie jednostronnie, tzn. aby uwzględnienie skargi kasacyjnej było warunkiem koniecznym, ale jeszcze nie wystarczającym, aby wystapić z powództwem o odszkodowanie przeciwko Skarbowi Państwa. Ani ten przepis, ani żaden inny nie przewiduje żadnych dodatkowych warunków, wobec czego powództwo takie jest dopuszczalne, co oczywiście nie przesądza, że odszkodowanie zostanie zasądzone.

Prawo materialne pozwoli także na odmowę zasądzenia czy zmniejszenie odszkodowania na rzecz takiej strony, która sama swoim działaniem spowodowała wadliwość pierwszego wyroku (np. przez wywołanie braków w jej reprezentacji przed sądem). Istnieje wówczas pełna możliwość zastosowania art. 362 k.c., czyli przyczynienia się poszkodowanego do wystapienia szkody.

\section{UWAGI DE LEGE FERENDA}

$\mathrm{Na}$ zakończenie podkreślić trzeba, że istotnie trafnie zwraca się uwagę zarówno w doktrynie, jak i w judykaturze na to, że regulacje proceduralne zwiąane z dochodzeniem odszkodowania z art. $417^{1} \S 2$ k.c. sa niejasne i niespójne. Wymagają wobec tego interwencji ustawodawcy zamiast dokonywa- 
nej interpretacji contra legem, gdyż za taką trzeba niestety uznać wykładnię art. $424^{1 \mathrm{a}} \S 2$ k.p.c. w taki sposób, że orzeczenia Sądu Najwyższego uwzględniające skargę kasacyjną nie traktuje się (jeszcze) jako uwzględnienie skargi o stwierdzenie niezgodności prawomocnego orzeczenia z prawem czy też zezwolenie na dochodzenie naprawienia szkody bez stwierdzenia we właściwym postępowaniu niezgodności orzeczenia z prawem (art. $417^{1} \S 2$ k.c.).

Nie ingerując zbytnio w kształt obecnych rozwiązań, można zaproponować jako postulat de lege ferenda, aby Sąd Najwyższy, rozpoznając skargę kasacyjna, od razu rozstrzygał o tym, czy bezprawność zaskarżonego wyroku jest tak poważna, że uzasadnia odpowiedzialność odszkodowawczą Skarbu Państwa.

Ocena taka powinna być dokonywana jedynie na wniosek skarżącego, który mógłby podlegać dodatkowej opłacie. Orzeczenie w przedmiocie niezgodności z prawem zapadałoby w formie odrębnego punktu wyroku czy postanowienia. Oczywiście mogłoby ono zapaść tylko w wyroku uwzględniającym skargę kasacyjna, jednak niezależnie od tego, czy ma on charakter reformatoryjny czy kasatoryjny. W przypadku składania tego wniosku należałoby także zrezygnować z wymogu uprawdopodabniania szkody, głównie z tego powodu, że wniosek musiałby być składany w skardze kasacyjnej, a więc dużo szybciej niż w terminie wskazanym w art. $424^{6} \S 1$ k.p.c. W tak krótkim terminie zebranie materiału wskazującego jednocześnie na uprawdopodobnienie szkody byłoby zbyt dużym obciążeniem dla strony ${ }^{26}$. Oczywiście powyższe zmiany zasługują na wprowadzenie tylko w przypadku, gdyby ustawodawca podzielił sposób pojmowania niezgodności prawomocnego orzeczenia z prawem w sprawach cywilnych, wypracowany w orzecznictwie Sądu Najwyższego, wymagajacy dla stwierdzenia niezgodności z prawem naruszenia o charakterze rażacym, kwalifikowanym, dostrzegalnym prima facie przez każdego prawnika. Bardziej celowe byłoby przy tym wprowadzenie domniemania bezprawności wyroku uchylonego albo uchylonego i zmienionego przez Sąd Najwyższy w wyniku uwzględnienia skargi kasacyjnej, z jednoczesnym umożliwieniem Skarbowi Państwa zwolnienia się z odpowiedzialności przez wykazanie, że popełniony błąd orzeczniczy był dopuszczalny, gdyż wynikał z atrybutów sprawowania władzy sędziowskiej.

Marcin Lemkowski

Uniwersytet im. Adama Mickiewicza w Poznaniu

marcin.l@amu.edu.pl

https://orcid.org/0000-0001-9213-6826

Bagińska, E. (2006). Odpowiedzialność odszkodowawcza za wykonywanie władzy publicznej. Warszawa.

Banaszczyk, Z. (2015). Odpowiedzialność za szkody wyrządzone przy wykonywaniu władzy publicznej. Warszawa.

${ }^{26}$ Zresztą obecnie wymogu takiego nie ma, jeśli prejudykatem ma być orzeczenie uwzględniające skargę kasacyjną. Przy tej okazji można by rozwiązać problem polegajacy na tym, że często szkoda nie ujawnia się od razu po wydaniu bezprawnego wyroku, lecz później, nawet po terminie do wniesienia skargi o stwierdzenie niezgodności orzeczenia z prawem. 
Bieniek, G. (2002). Odpowiedzialność Skarbu Państwa za szkody wyrządzone przez funkcjonariuszy - po wyroku Trybunału Konstytucyjnego z dnia 4 grudnia 2001 r. Przegląd Sądowy 12(4): $3-25$.

Ereciński, T. (2016). [Komentarz do art. 398 ${ }^{15}$ ], [w:] T. Ereciński (red.), Kodeks postępowania cywilnego. Komentarz. Tom 3: Postępowanie rozpoznawcze. Warszawa: 294-299.

Gęsiak, J. (2007). Prejudykat a odpowiedzialność za szkodę wyrządzoną wydaniem orzeczenia w postępowaniu cywilnym. Przegląd Sądowy 17(7/8): 79-95.

Gudowski, J. (2016). [Komentarz do art. 4241a], [w:] T. Ereciński (red.), Kodeks postępowania cywilnego. Komentarz. Tom 3: Postępowanie rozpoznawcze. Warszawa: 478-479.

Gudowski, J. (2006). Węzłowe problemy skargi o stwierdzenie niezgodności z prawem prawomocnego orzeczenia. Przegląd Sądowy 16(1): 3-22.

Lemkowski, M. (2017). O pojmowaniu niezgodności prawomocnego orzeczenia z prawem w sprawach cywilnych w orzecznictwie Sądu Najwyższego. Przegląd Sądowy 4: 24-40.

Pietrzkowski, H. (2005). Skarga o stwierdzenie niezgodności z prawem prawomocnego orzeczenia. Przegląd Sądowy 15(4): 3-17.

Sieńko, M. (2015). [Komentarz do art. 424 ${ }^{1 \mathrm{a}}$ ], [w:] M. Manowska (red.), Kodeks postępowania cywilnego. Komentarz. Tom 1: Art. 1-50538. Warszawa: 1118-1119.

Skoczylas, J.J. (2005). Odpowiedzialność za szkody wyrządzone przez władzę publiczną. Warszawa.

Wiśniewski, T. (2013). [Komentarz do art. $398^{16}$ oraz do art. 4241a], [w:] H. Dolecki, T. Wiśniewski (red.), Kodeks postępowania cywilnego. Tom 2: Artykuły 367-505 ${ }^{37}$. Warszawa: 261-264, $362-363$.

Zembrzuski, T. (2015). Komplementarność nadzwyczajnych środków zaskarżenia - skarga kasacyjna a skarga o stwierdzenie niezgodności z prawem prawomocnego wyroku, [w:] M. Michalska-Marciniak (red.), Wokół problematyki środków zaskarżenia w postępowaniu cywilnym. Sopot: 229-260.

\section{SUCCESSFUL CASSATION TO THE SUPREME COURT AS A BASIS FOR CLAIMING DAMAGES FOR ERRONEOUS COURT DECISIONS}

\section{Sum mary}

This article refers to the liability of the State Treasury for damages for erroneous court decisions in civil cases. To be able to sue the State Treasury for damages, the claimant must first obtain a Supreme Court decision. The Polish Code of Civil Procedure provides for a separate claim to determine that the court decision is in breach of the law, but there is also a regulation by which a successful cassation to the Supreme Court is to be an equivalent of that procedure and allows the claimant to sue for damages. This equivalent regulation, albeit with regard to legal provisions, is not accepted in the reported cases, and this provides grounds for the criticism in the article.

Keywords: erroneous decisions of courts; State Treasury; liability; damages; gross breach of the law 